ENVIRONMENTAL CONFLICTS:

THE CASE OF ACID RAIN IN EUROPE

Jean-Paul Hettelingh and Leen Hordijk

International Institute for Applied Systems Analysis

Laxenburg, Austria

RR-87-9

June 1987

Reprinted from Annals of Regional Science, volume 20 (1986).

INTERNATIONAL INSTITUTE FOR APPLIED SYSTEMS ANALYSIS

Laxenburg, Austria 
Research Reports, which record research conducted at IIASA, are independently reviewed before publication. However, the views and opinions they express are not necessarily those of the Institute or the National Member Organizations that support it.

Reprinted with permission from Annals of Regional Science, 20 (1986), 38-52.

Copyright @ 1986, Annals of Regional Science (Bellingham, WA, USA).

All rights reserved. No part of this publication may be reproduced or transmitted in any form or by any means, electronic or mechanical, including photocopy, recording, or any information storage or retrieval system, without permission in writing from the copyright holder.

Printed by Novographic, Vienna, Austria 


\section{FOREWORD}

This paper describes the use of the IIASA RAINS model as a decision-support tool for conflict resolution with respect to the European acid rain issue. It is important that the results of IIASA research be disseminated in peer-reviewed journals, and this reprint is one example of the effective publication program of the Acid Rain Project.

R.E. MUNN

Leader, Environment Program

International Institute for Applied Systems Analysis 


\title{
ENVIRONMENTAL CONFLICTS: THE CASE OF ACID RAIN IN EUROPE
}

\author{
Jean-Paul Hettelingh and Leen Hordijk \\ Acid Fain Project \\ International Institute for Applied Systems Analysis \\ A-2361 Laxenburg \\ Austria
}

Abstract

The Acid Rain problem is transboundary in nature: sulfur emissions in one country may lead to desposition of sulfur in a receptor country. A policy conflict may arise in estimating the damage at some receptor due to the various pollutant sources.

This paper first reviews the international policy context that led to the development of the Regional Acidification Informational and Simulation (RAINS) model. The model computes sulfur emissions, transport and deposition which is then transferred into soil and lake acidity. The model is an interactive tool designed to assist policy makers in evaluating the effect of the control measures related to sulfur emissions. A mathematical description of the model is provided followed by a set of objective functions to be introduced within the P.AINS model. The current interactive usage of RAINS will be extended with the possibility for the decision maker to progressively define objectives and set constraints in order to obtain an optimal policy.

\section{Introduction}

International attention concerning the problem of long-range transport of air pollutants started in 1972, just before the United Nations Conference on the Human Environment in Stockholm [17]. In April of that year the Organization for Economic Cooperation and Development (OECD) inaugurated a "Cooperative Technical Program to Measure the Long-Range Transport of Air Pollutants" in which eleven European nations participated. In 1979 a revised publication of the Program's findings was published [12]. It was reported that a substantial part of a country's emissions of $\mathrm{SO}_{2}$ was transported hundreds of kilometers and deposited in other countries. Emissions originating in the United Fingdom thus affected lakes in Scandinavia, and Austrian deposition levels were increased by emissions in the German Democratic Republic. Although the results of the OECD study carried an uncertainty of a factor of two, many European countries accepted the major conclusions of the report. At the same time it was clear that the geographical scope of OECD was too small to realistically discuss the long-range transport problem. Therefore the discussion of the problem shifted from OECD (with no Eastern European participants) to the United Nations Economic Commission for Europe (ECE), including entire Europe, Canada and the 


\section{ENVIRONMENTAL CONFLICTS: THE CASE OF ACID RAIN IN EUROPE}

United States of A merica. In 1979 the Convention on Long-Range Transboundary Air Pollution was signed by 32 European countries, the European Economic Community (EEC), Canada and the USA. In the process of formulating the Convention, it turned out that resistance to an agreement did not come from Eastern European countries but from the Federal Republic of Germany (FPC) and the United Kingdom. The British scientists recognized the Scandinavian problems, but objected that it was not certain that these problems were (partly) due to Britain's emissions. The FRG turned into a supporter of reduction policies after it was discovered that large areas of its forests had been damaged by air pollution [17]. Notwithstanding this resistance the Convention was signed in November 1979 and ratified on 16 March 1983 by the required minimum number (24) of the signatories. The Convention entails no binding commitment to undertake measures, but the Contracting Parties endeavour "to limit and, as far as possible, gradually reduce and prevent air pollution, including long-range transboundary air pollution" (article 2). Ey article 3 the Contracting Parties "shall by means of exchanges of information, consultations research and monitoring develop without undue delay, policies and strategies which shall serve as a means of combating the discharge of air pollutants." Although the Convention covers all types of air pollutants, priority was given to sulfur compounds. At its third meeting, the Executive Body of the Convention (July 1985, Helsinki) established a working group on nitrogen compounds.

Jointly with the World Meteorologic Organization (WMO) the ECE is responsible for the Co-operative Programme for Monitoring and Evaluation of Long-Range Transmission of Air Pollutants in Europe (EMEP). The EMEF sampling network provides a database of concentrations and depositions of air pollutants (mostly sulfur compounds), and in particular provides information for validating the models for long-range transport of air pollutants developed at the $N$. eteorological Synthesizing Centres in Oslo and Moscow [7]. At the end of the second phase of EMEP (1983), 81 monitoring stations in 22 countries were in operation.

The Convention's Working Group on Effects is producing reviews of current knowledge about effects of air pollution, in particular acidification. Also three international cooperative programmes were initiated in $1985 / 86$, namely, Material Exposure Programme, Assessment and Monitoring of Acidification of Rivers and Lakes, and Assessment and Monitoring of Air Pollution Effects on Forests.

In July 1385 a Protocol was added to the Convention. The Protocol, an internationally binding agreement stating that sulfur emissions or transboundary fluxes will be reduced by at least $30 \%$ as soon as possible and at the latest by 1993 (using 1980 levels as the basis for calculation of reductions), has been signed by 21 parties to the Convention. Among countries that did not sign the protocol are large emitters, e.g., the United Kingdom and Poland, and small south European countries like Greece and Portugal. In Eastern Lurope only Romania did not sign the Protocol, whereas the Soviet Union's interpretation of the Protocol is in terms of transboundary fluxes rather than in total emissions.

After establishing the Protocol, which by many countries was considered to be a first political step towards reduction of acidification, an international discussion has started about further steps. Important in this discussion are two issues: (1) Can threshold levels of effects be determined? (2) In which way ean a flat-rate-of-reduction policy be changed? To answer the first question a large amount of detailed information about acidification effects on lakes, rivers, materials and monuments, forests, crops, soils and groundwater is needed. In 


\section{JEAN-PAUL HETTELINGH AND LEEN HORDIJK}

addition the vulnerable areas in Europe need to be determined. The cooperative programmes of the Convention should provide this information. Together with the knowledge about atmospheric linkages between sources and receptors it should then be possible to derive policies which are different from the current uniform reduction, and which are advantageous in terms of reducing costs and/or increasing environmental production.

Although the results of the EMEP long-range transport of air pollutants model (see [12] and [7]) are generally accepted, one may wonder whether the same will be true for a scientific evaluation of effects of air pollution. It is the authors' belief that long negotiations between Signatories to the Convention will be needed before any agreement other than flat rate reductions can be achieved. First of all, establishing threshold levels will be accompanied with large uncertainties. Second, determination of the vulnerable areas (the stock at risk) will cause intense disputes about the spatial distribution of such areas. For these reasons negotiations might be lengthy, possibly unresolved for ten years or more. Furthermore, investigations into the role of nitrogen compounds have just started, and results will bear influence on the choice of threshold levels and vulnerable areas. Consequently the acid deposition dispute in Europe might continue for some time before further action is taken.

In this paper we will briefly outline an acidification model for Europe which is constructed in order to assist policy makers and their technical advisors. The model has been described inter alia in [1] and is known as the Regional Acidification Information and Simulation (RAINS) model. Next we will present the mathematical form of the model. Finally we formulate some multiobjective optimization problems. But first we will give a short overview of emissions of $\mathrm{SO}_{2}$ and deposition of sulfur compounds to familiarize the reader with the European situation. In Table 1 the $\mathrm{SO}_{2}$ emissions in the year 1980 for 27 larger European countries are given. The numbers are given in kilotonnes of sulfur per year.

TABLE 1

EMISSION OF $\mathrm{SO}_{2}$ IN EUROPEAN COUNTRIES IN 1980 IN KILOTONNES CF SULPHUR (COLUMN 1) AND CUPRENT REDUCTION PLANS (COLUNN 2).

\begin{tabular}{lrrlrr}
\hline \hline Country & $(1)$ & $(2)$ & Country & $(1)$ & $(2)$ \\
\hline Albania & 39 & 0 & Italy & 1898 & 30 \\
Austria & 159 & 50 & Luxembourg & 20 & 30 \\
Belgium & 432 & 50 & Netherlands & 243 & 60 \\
Eulgaria & 508 & 30 & Norway & 72 & 50 \\
Czechoslovakia & 1832 & 30 & Poland & 1741 & 0 \\
Denmark & 226 & 50 & Portugal & 130 & 0 \\
Finland & 294 & 50 & Romania & 757 & 0 \\
France & 1657 & 50 & Spain & 1879 & 0 \\
Fed.Rep. Germany & 1602 & 60 & Sweden & 243 & 65 \\
German Dem. Rep. & 2415 & 30 & Switzerland & 67 & 30 \\
Greece & 345 & 0 & Turkey & 497 & 0 \\
Hungary & 813 & 30 & United Kingdom & 2342 & 0 \\
Ireland & 119 & 0 & USSR (European part) & 8588 & 30 \\
& & & Yugoslavia & 837 & 0 \\
n & & Europe & 29755 & 25
\end{tabular}

${ }^{1}$ To obtain emissions in kilotonnes of sulfur dioxide the numbers have to be multiplied by a factor of 2 . 


\section{ENVIRONMENTAL CONFLICTS: THE CASE OF ACD RAIN IN EUROPE}

As described previously, many countries are prepared to reduce their sulfur dioxide emissions by at least $30 \%$ based on 1980 levels. The second column of Table 1 shows percentage reductions for the European countries.

Figure 1 presents a three-dimensional picture of calculated deposition for 1980. The calculation is based on the ENEP-W model, see [7] for a description of this model. Figure 1 also indicates the ten areas with the highest 1980 deposition levels as calculated by the model. These areas and their locations are presented in Table 2.

TABLE 2

TEN AREAS IN EUROPE WTH THE HIGHEST CALCULATED DEPOSITION

\begin{tabular}{lll} 
& LEVELS IN 1980 & \\
\hline Area & $\begin{array}{l}\text { Approxim ate } \\
\text { longitude/latitude }\end{array}$ & Country \\
\hline Donetz & $39 / 47.5$ & USSR \\
Erzgebirge & $13 / 51$ & GDR/CSSR \\
Katowice & $19 / 50$ & Poland \\
Bilo Gora & $17 / 46$ & Yugoslavia \\
L.ombardy & $9 / 46$ & Italy \\
Burzsony Hills & $19.5 / 48$ & Hungary \\
Phineland & $7 / 51$ & F R G \\
West Yorkshire & $-2 / 53^{*}$ & United Kingdom \\
Belgrade & $21 / 45$ & Yugoslavia \\
Moscow & $39 / 56$ & USSR \\
\hline
\end{tabular}

*-2 indicates two degree west of Greenwich

II. The RAINS Model

RAINS consists of four submodels [1], [2]:

1. The sulfur emissions submodel;

2. The deposition submodel;

3. The for est soil acidification submodel;

4. The lake acidification subm odel.

The time span of the model is from 1960 to 2040. It includes all of Europe except for the lake acidification submodel which is currently limited to Finland and Sweden. A user starts with the sulfur emissions submodel by defining a sulfur abatement strategy on one of five energy scenarios or on a previously defined abatement strategy. The sulfur emissions thus computed enter into the deposition submodel where the sulfur deposition in 2473 longitude-latitude grid points is calculated. ${ }^{2}$ The soil submodel takes these depositions as a starting point in calculating acidification, measured in $\mathrm{HI}^{+}$concentrations and uses the dominant for est soil types ${ }^{3}$ by means of relevant soil chemistry.

${ }^{2}$ The European area consicered is bound by $-12^{\circ}$ longitude, $35^{\circ}$ latitude and $42^{\circ}$ longitude, $74^{\circ}$ latitude. The grid size is 1 degree longitude by 0.5 degree latitude. 1974.

${ }^{3}$ FAO UNESCO Soil Niap of the World, Vol. 1, V, FAO-UnESCO, Paris, 


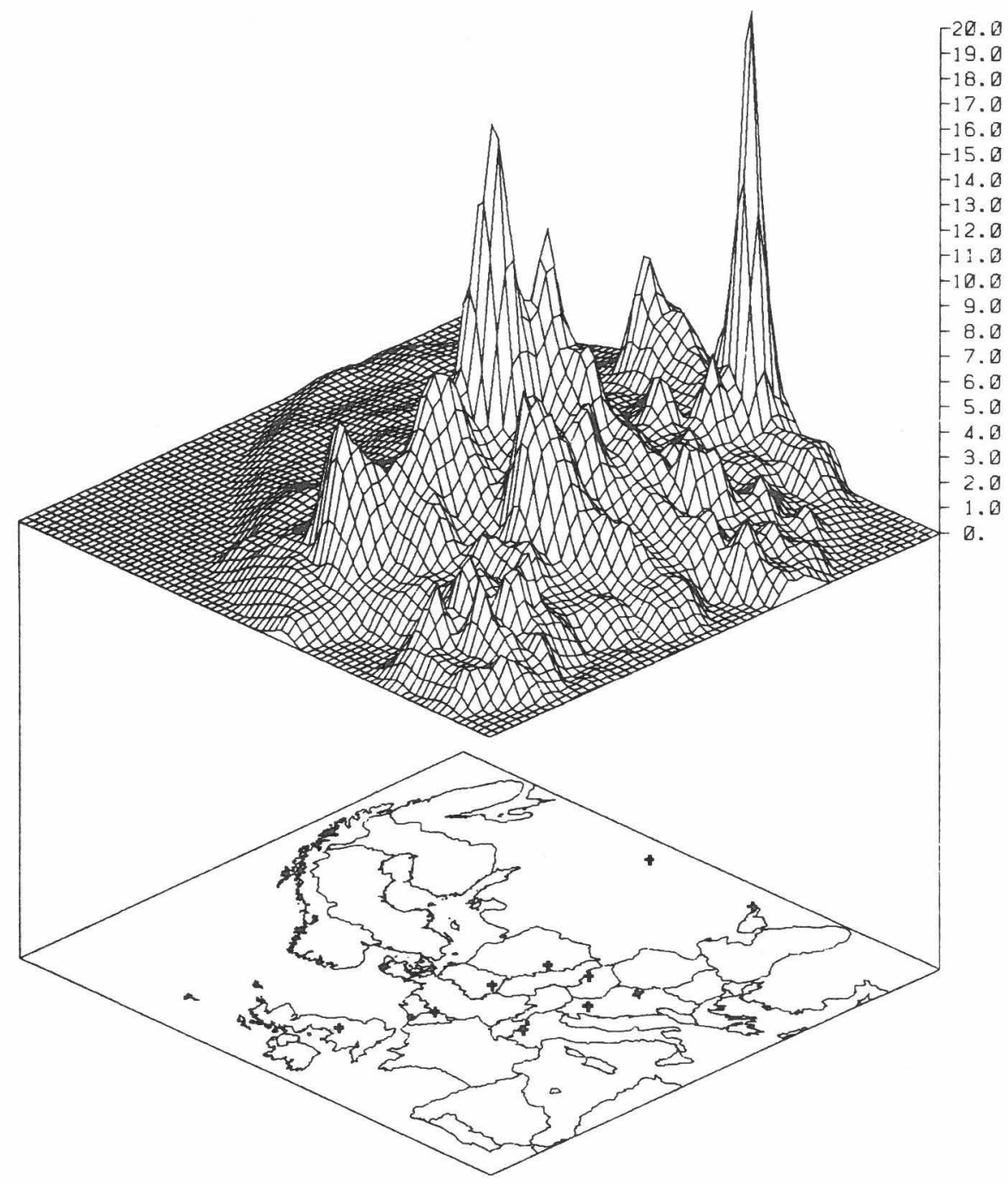

Figure 1. Calculated deposition (gram S/m $2 / \mathrm{yr}$ ) in Europe, 1980. The ten highest deposition areas are indicated on the map. 


\section{ENVIRONMENTAL CONFLICTS: THE CASE OF ACID RAIN IN EUROPE}

The final submodel, the lake acidification submodel, also uses sulfur deposition as an input variable. In addition a detailed simulation is used for the top soil water flows towards the lake. Those water flows are simulated taking into account precipitation and snowmelt. Separate modules are used for these simulations. In the following mathematical description the first three submodels are formalized. The lake model is described in a non mathematical way. In the description the model the following subscripts are used:

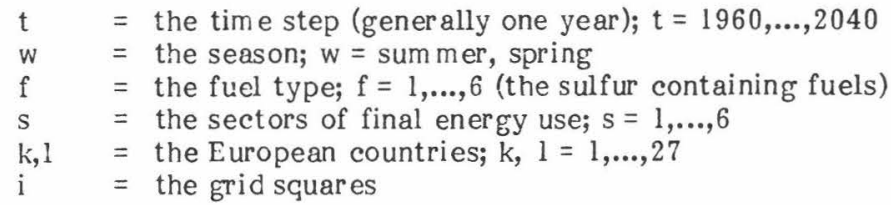

Upper case letters are used to indicate flow and stock variables, lower case letters are used for fractions and per unit variables.

\section{II.1 The Sul fur Emissions Subm odel}

The basis of this submodel are five energy scenarios to 2040 , three being based on published estimates to 2000 from the ECE [6] and two on IFA energy pathways to 2000 [9]. The energy scenarios comprise eight fuel types ${ }^{4}$ being used in six sectors ${ }^{5}$ of final energy use. For each of the fuel types and each of the sectors, the following computation is done to obtain sulfur emissions for every country for every year.

$$
S_{f, s, k, t}=E_{f, s, k, t} \cdot s_{f, s, k, t} \cdot \frac{1}{h_{f, k}}\left(1-p_{f, s, k, t}\right)\left(1-r_{f, k}\right)
$$

where $E=$ energy demand in $\mathrm{PJ}$ of fuel type $\mathrm{f}$ in sector $\mathrm{s}$, country $k$ and year $\mathrm{t}$

$\mathrm{S}=$ sulfur emission

$\mathrm{s}=$ sulfur content

$\mathrm{h}=$ heat value

$\mathrm{p}=$ fraction of sulfur removed by pollution control measures

$\mathrm{r}=$ fraction of sulfur retained in ash

Sulfur emissions are obtained after defining pollution control measures, e.g. the use of low sulfur fuel, flue gas desulfurization and combustion modification. The deposition submodel requires the total country emissions obtained as:

$$
\mathrm{S}_{\mathrm{k}, \mathrm{t}}=\sum_{\mathrm{f}} \sum_{\mathrm{S}} \mathrm{S}_{\mathrm{f}, \mathrm{s}, \mathrm{k}, \mathrm{t}}
$$

Efforts are being made to introduce in the emissions submodel costs of the pollution control measures for each country in Europe. The cost functions

${ }^{4}$ The fuel types being distinguished are hard coal, brown coal, derived coal, hęavy oil, light oil, crude oil, natural gas and others.

${ }^{5}$ The energy sectors are conversion, conventional power plants, domestic, incustry, transport and others. 


\section{JEAN-PAUL HETTELINGH AND LEEN HORDIJK}

developed depend on a subset of technological variables (cleaning efficiency, capacity factor, etc.) on a yet to be determined aggregation level. This "medium" aggregation level is feasible but also credible in that it distinguishes country cost estimates in a physically realistic manner. Cost functions developed for each of the 27 countries considered are of the form:

$$
C_{k, t}\left(R_{k, t}\right)=f \text { (technological variables) }
$$

where $\quad R=$ Reduction of emissions in country $k$

$\mathrm{C}=$ Cost as function of emission reduction

\section{II.2 The deposition submodel}

The primary aim of this submodel is to translate emissions into deposition in each of the European grid squares mentioned earlier. For this purpose a source-receptor matrix is used that is based on a model of long range transport of air pollutants in Europe developed under the Organization of Economic Cooperation and Development (OECD) and the Cooperative Program for the Monitoring and Fvaluation of Long Range Transmission of Air Pollutants in Europe (ENI.P). This EMEP-W model (see [7] for a description) calculates concentrations of $\mathrm{SO}_{2}$ and $\mathrm{SO}_{4}=$ at the center of grid elements. Every 6 hours air trajectories are computed backward from the center of each grid and are followed 96 hours later. The model then solves the mass balance equations along the trajectory. Dry and wet deposition are calculated using the $\mathrm{SO}_{2}$ and $\mathrm{SO}_{4}=$ concentrations. The EMEP-W model is too demanding computationally to be used directly as a submodel of RAINS. Therefore a source-receptor matrix has been derived for several years (1978-1982). The elements of this matrix (sometimes referred to as transfer coefficients) represent the deposition per unit area per unit time for one unit emission.

Total deposition per grid is calculated as:

$$
\mathrm{D}_{\mathrm{i}, \mathrm{t}}^{\text {tot }}=\sum_{\mathrm{k}} \mathrm{S}_{\mathrm{k}, \mathrm{t}} \mathrm{a}_{\mathrm{k}, \mathrm{i}}
$$

with $\mathrm{D}^{\text {tot }}=$ total deposition in grid square $\mathrm{i}$ at time $\mathrm{t}$

$\mathrm{a}=$ element of the source-receptor matrix from country $\mathrm{k}$ to grid square i

\section{II.3 The Forest Soil A cidification Submodel}

Soil acidification is defined as a decrease in the acid neutralization capacity of the soil [3]. In order to simulate such decreases, soil chemistry reactions have been classified into five classes of acid buffering reactions [15], [16]. Two buffering variables, buffer capacity and buffer rate, determine the soil's capacity to counteract acidic deposition. The buffer capacity is the total reserve of buffering compounds within one class. The buffer rate is the maximum potential rate of the reaction between the buffering compounds and the hydrogen ions. In Table 3 , an incomplete ${ }^{6}$ overview is given of the different buffer range classes, the related acidity measure, $\mathrm{pH}^{7}$ and the buffering variable to be applied.

\footnotetext{
${ }_{7}^{6} \mathrm{~A}$ complete table can be found in [11].

${ }^{7} \mathrm{pH}=-{ }^{10} \log \left[\mathrm{H}^{=}\right],\left[\mathrm{H}^{+}\right]$being the concentration of hydrogen ions.
} 
ENVIRONMENTAL CONFLICTS: THE CASE OF ACID RAIN IN EUROPE

TABLE 3

CLASSIFICATION OF THE ACID BUFFERING REACTIONS IN FCREST SOILS

\begin{tabular}{lll}
\hline \hline Buffer Range & pH Range & Buffering variable \\
\hline Carbonate & $8.0-6.2$ & buffer capacity \\
Silicate & $6.2-5.0$ & buffer rate \\
Cation exchange & $5.0-4.2$ & buffer capacity \\
Aluminum & $4.2-3.0$ & buffer rate \\
\hline
\end{tabular}

Acid deposition results in an input of hydrogen ions, $\mathrm{H}^{+}$, into the top soil. This process is termed "acid stress." The equations below describe the balance between acid stress and the buffering variables on the portions of the grid squares cover ed by forests.

The first step towards the calculation of the acidity is to compute the fraction of the total deposition that applies to forest soils only, and translate that into acid stress.

$$
\text { as }_{\mathrm{i}, \mathrm{t}}=\mathrm{C} \cdot \mathrm{r} \mathrm{i}_{\mathrm{i}, \mathrm{t}}^{\mathrm{tot}}
$$

with as $=$ acid stress in $\mathrm{kmol} \mathrm{ha}^{-1} \mathrm{yr}^{-1}$ in grid square $\mathrm{i}$ at time $\mathrm{t}$

$\mathrm{L}^{\text {tot }}=$ total (wet and dry) deposition

$\mathrm{C}=$ constant accounting for the fraction of the total deposition on forest soils and balancing the measurement units.

Next, this acid stress is confronted with the buffer range hierarchy outlined in Table 3. As long as the carbonate buffer range has not been depleted, the pHI is kept constant. For the silicate and cation exchange buffer range the following relation holc's:

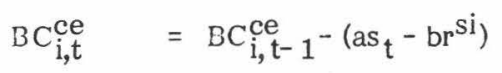

with $\mathrm{BC}^{\mathrm{ce}}=$ buffer capacity in the cation exchange range

$\mathrm{br}^{\mathrm{Si}}=$ buffer rate in the silicate buffer range

For acidity ranging between a pH value of 5.6 and a $\mathrm{pH}$ value of 4.0 , a non-linear relationship is assumed between the remaining buffer capacity, expressed as percentage of the total buffer capacity, and the silicate, cation exchange and the upper aluminum buffer ranges [13]:

$$
\mathrm{pH}_{\mathrm{i}, \mathrm{t}}=4.0+1.6\left(\mathrm{BC}_{\mathrm{i}, \mathrm{t}}^{\mathrm{ce}} / \mathrm{CEC}^{\mathrm{tot}}\right)^{3 / 4} \text { for } \mathrm{pH}_{\mathrm{t}-1} \geq 4.0
$$

where $\mathrm{pH}$ measure for acidity (see note 6 )

$$
\mathrm{CEC}^{\text {tot }}=\text { total cation exchange capacity }
$$

Once the buffer capacity of the cation exchange range is depleted the aluminum buffer range is simulated to meet equilibrium assumptions between the concentrations of aluminum ions and hydrogen ions. The simulation takes into account the soil thickness, the w.ater contained in the soil layer and the net annual precipitation. Specifying all the equations involved is outside the scope 
of this paper. (Details can be found in [11].) The final equation can be summ arized as follows:

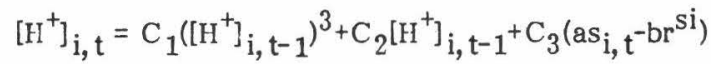

$$
\begin{aligned}
& -\mathrm{C}_{4}\left(\left[\mathrm{H}^{+}\right]_{\mathrm{i}, \mathrm{t}}\right)^{3} \text { for } \mathrm{pH}_{\mathrm{t}-1}<4.0
\end{aligned}
$$

with $\left[\mathrm{H}^{+}\right]$

$=$ concentration of the hydrogen ions

$$
\begin{aligned}
\mathrm{C}_{1}, \mathrm{C}_{2}, \mathrm{C}_{3}, \mathrm{C}_{4}= & \text { constants involving water volume, net precipitation } \\
& \text { and an equilibrium level at which alum inum may be } \\
& \text { dissolved or precipitated. }
\end{aligned}
$$

By substituting equations (5) and (6) into equation (7) the soil acidification at time $\mathrm{t}$ is computed under the condition that the soil acidity at time $\mathrm{t}-1$ was greater than or equal to 4.0. Otherwise the soil acidification is simulated using equation ( 8 ). This equation can be solved recursively. ${ }^{8}$ The simulation is done for every grid square and soil type in Europe.

\section{4 The Lake Acidification Submodel}

The lake acidification submodel consists of four modules for meteorology, hydrology, soil chemistry and lake acidity. Thi submodel is described in detail in [10]. The simulation is done for a monthly time step finally resulting in an average spring- and summer-acidity level for each year. Since a detailed mathematical description of each of the modules is outside the scope of this paper, only the purpose of each of the modules is described.

The meteorologic module determines the precipitation and the sulfur deposited on the area considered to be relevant for describing waterflows to the lake area concerned. This area is called the terrestrial catchment area.

Total precipitation, divided into rain and snow using threshold temperatures, is computed in order to determine the part of sulfur deposition that is accumulated in the snowpack and the part that is released in the snowmelt. The final output variable of this module is the acid stress:

$$
a s_{t}=D^{\text {tot }}-D_{t}+D_{t}
$$

with

$$
\begin{array}{ll}
\text { as } & =\text { acid stress } \\
\mathrm{D}^{\text {tot }} & =\text { total sulfur deposition } \\
\mathrm{D}^{\mathrm{S}} & =\text { deposition accumulated in the snow pack } \\
\mathrm{D}^{\mathrm{m}} & =\text { deposition released from the snowpack. }
\end{array}
$$

This variable is used in the soil chemistry module. For this purpose a description is needed of the flows of rain and snowmelt water towards the lake. This is done in the hydrologic module. In this module, the catchment area is vertically segmented in two soil layers, ealled the A- and B reservoirs. The A reservoir is defined as the upper $0.5 \mathrm{~meter}$ soil layer. Physically, the flow from the upper reservoir can be thought of as quickflow, which drains cown the hillsides and enters the brooks directly. A part of the content of the $A$ reservoir enters the $B$

${ }^{8}$ In fact $\mathrm{C}_{1}=\mathrm{C}_{2} \times \mathrm{C}_{4}$ so that recursion can easily be implemented. The final third order equation may then be solved using Cardanno's rule resulting in a single real root for the concentration of hydrogen ions. 


\section{ENVIRONMENTAL CONFLICTS: THE CASE OF ACID RAIN IN EUROPE}

reservoir. This depends on the percolation rate, the water volume in the $\mathrm{A}$ reservoir and the space left in the B reservoir. The latter reservoir provides the baseflow coming from deeper soil layer [5]. The rate with which the water is discharged from the B reservoir to streams and lakes is limited by hydraulic conductivity, surface slope, soil moisture, catchment width and terrestrial catchment area. The volumes of $\mathrm{A}$ - and $\mathrm{B}$ reservoir are used in the soil chemistry module to compute the acid stress within the two reservoirs. The soil chemistry module resembles equations (5) to (8) with the difference that two soil layers are used. The acid stress in the $A$ layer is defined by equation (5) while the acid stress in the B-layer is defined as a function of both the acid stress in the A layer and the percolation rate from the A to the B reservoir.

The final output of the soil chemistry module is the quantity of acidity and the quantity of alkalinity. Alkalinity expresses the total buffer capacity of the lake water. In the lake module the output variables of the soil chemistry module, are used to compute the concentration of $\mathrm{H}^{+}$ions. The resul ts presented to the user of RAINS are average pH levels in the spring and in the summer. In the remainder of this paper the outcome of the lake submodel will have the following notation:

$$
\left[\mathrm{H}^{+}\right] \mathrm{w}, \mathrm{t}=\begin{aligned}
& \text { lake } \mathrm{H}^{+} \text {concentration in season } \mathrm{w} \text { (summer or spring) } \\
& \text { of year } \mathrm{t}
\end{aligned}
$$

\section{Multiple Objective Decision Miaking in RAINS}

In order to tackle environmental problems in general, a multidisciplinary approach is most appropriate [4]. As illustrated by the discussion of the RAINS model above, the acidification problem is multidisciplinary; economic, energy and environmental aspects must be modeled. The use of multiple objective clecision making (MODN?) in a mul tidisciplinary context is not new [14]. Such an application of MODM using the RAINS framework is suggested below. The approach is under development within RAINS and consequently the following discussion is tentative.

$V$ ariables and indicators modeled with RAINS that may be of interest to the decision makers (DN?) include;

$$
\begin{aligned}
& \mathrm{S}_{\mathrm{k}, \mathrm{t}} \quad=\text { sulfur emissions in country } \mathrm{k} \text { at year } \mathrm{t} \text { (equation (2)) } \\
& \mathrm{R}_{\mathrm{k}, \mathrm{t}} \quad=\text { the emission reduction in country } \mathrm{k} \text { at year } \mathrm{t} \\
& \mathrm{C}_{\mathrm{k}, \mathrm{t}}^{\mathrm{k}, \mathrm{t}}\left(\mathrm{r}_{\mathrm{k}, \mathrm{t}}\right) \quad=\text { the cost of emission reduction in country } \mathrm{k} \text { at year } \mathrm{t} \\
& \text { tot (equation (3)) } \\
& \mathrm{D}_{\mathrm{i}, \mathrm{t}}^{\text {tot }} \quad=\text { total deposition in grid square } \mathrm{i} \text { at year } \mathrm{t} \text { (equation (4)) } \\
& {\left[\mathrm{II}^{+}\right] \mathrm{i}, \mathrm{t}=\text { concentration of } \mathrm{II}^{+} \text {ions in forest soils of }} \\
& \left.\mathrm{III}^{+}\right]_{\mathrm{W}, \mathrm{t}} \quad \begin{array}{c}
\text { grid square } \mathrm{i} \text { at year } \mathrm{t} \text { (equations }(7) \text { and }(8) \text { ) } \\
\text { (equation } 10 \text { )) }
\end{array}
\end{aligned}
$$

Several MODM will be formulated and discussed which used these variables and indicators of economic and environmental impacts. Only a few examples are given; other formulations are possible, especially considering the large temporal and spatial scales of RAINS and the adverse impacts of acidrain in Europe.

Decision making in acid rain abatement can be considered at national, 
bilateral and multilateral levels. At the national level a country considers only its own costs and effects. At the bilateral level a country aims at optimizing its abatement strategy considering deposition and environmental effects in one other country. Finally, a multilateral approach can be taken: all European countries together try to optimize their efforts in order to reach specified deposition and effect levels.

At the national level the objective for a country (irrespective of adverse effects outside that country), could be cost minimization subject to meeting required of national emission standards:

$$
\begin{gathered}
\min C_{k, t}\left(R_{k, t}\right) \\
\text { s. t. } S_{k, t}-R_{k, t} \leq \bar{S}_{k, t} \\
R_{k, t} \geq 0
\end{gathered}
$$

with $\overline{\mathrm{S}}_{\mathrm{k}, \mathrm{t}}=\begin{aligned} & \text { sulfur emission standard, representing, for example, the } 30 \% \\ & \text { reduction agreed to by many countries in } 1985 .\end{aligned}$

This optimization problem can be extended by including standards for deposition in (certain areas of) the country and targets for environmental effects:

$$
\begin{aligned}
& \min C_{k, t}\left(R_{k, t}\right) \\
& \text { s.t. } \sum_{i} w_{i}\left(S_{k, t}-R_{k, t}\right) a_{k, i} \leq \bar{D}_{k, t} \\
& \text { or } \sum_{i} w_{i}\left[H^{+}\right]_{i, t} \geq\left[H^{+}\right]_{k, t} \\
& \quad R_{k, t} \geq 0
\end{aligned}
$$

with $\mathrm{D}=$ deposition standard in country $\mathrm{k}$ at time $\mathrm{t}$ due to

$$
\begin{array}{ll}
{\left[\mathrm{HI}^{+}\right]} & =\begin{array}{l}
\text { emissions of country } \mathrm{k} \text { in grid square } \mathrm{i} \text { of country } \mathrm{k} . \\
\mathrm{w} \\
\text { weight representing spatial factors, e.g. vulnerability of } \\
\text { ecosystems }
\end{array}
\end{array}
$$

In a bilateral framework the NOLN problems can be formulated as:

$$
\begin{array}{ll}
\min C_{k, t}\left(R_{k, t}\right) \\
\text { s.t } & \sum_{i} w_{i}\left(S_{k, t}-R_{k, t}\right) a_{k, t} \leq \bar{D}_{1, t} \\
\text { or } & \sum_{i} w_{i}\left[H^{+}\right]_{i, t} \leq\left[\bar{H}^{+}\right]_{1, t} \\
& R_{k, t} \geq 0
\end{array}
$$

with 1 referring to the country where the effects in grid square $i$ of emissions of country $k$ are to be reduced.

The most interesting case is the multilateral problem of acic rain abatement. Before formulating some MODM problems, several observations of a technical and political nature will be made. Currently the common policy in 
Europe is a source reduction policy; the Helsinki protocol (see section I) requires a $30 \%$ reduction of emissions. An alternative approach would be to aim at targeted levels of deposition (or soil or lake acidification). As mentioned at the outset, such environmental criteria will be difficult to determine. However, the uncertainty of appropriate thresholds will reduce in time with additional research. A drawback of the targeted reduction approach is that for some participating countries the costs of control policies will be much lower than the benefits. Some countries could be unwilling to contribute to better environmental conditions in other countries, if this would imply high costs to them. In fact there are countries where the economic circumstances are such, that one cannot expect substantial investments in pollution control for years to come. Furthermore, one has to consider technological constraints. A country might argue that the structure of its electricity producing sector does not allow a rapid implementation of new (abatement) technologies. In some cases reduction resulting from optimization might be achieved a decade later than required. Altogether these economic, technologic and political observations indicate a difficult environment to negotiate a common European policy for reducing adverse effects of acidrain. A technical way out of this situation could be an agreement that allows for cost sharing via a European fund for the abatement of air pollution. Such a policy would imply abandoning the "polluters pay principle" which is currently generally accepted throughout the continent.

There are many ways to formulate a MODM problem that takes into account the above observations. Two alternative formulations for the international problem are proposed. In the first formulation the target is to minimize the sum of recuctions in all countries under two constraints. The first constraint sets upper bounds on deposition levels in a number of selected grid elements. The second constraint represents a European fund for acid rain abatement. The origin and amount of the fund are left open in this formulation. Depending on the selection of target areas the solution of this optimization problem could include a number of countries where no emission reductions are required. To avoid this a lower bound on reductions could be added, either in terms of tonnes of reduction implemented or planned reductions or in money terms (based, for example, on already decided reductions). The MODN: formulation of this problem is as follows:

$$
\begin{aligned}
\min & \sum_{\mathrm{k}} \mathrm{R}_{\mathrm{k}, \mathrm{t}} \\
\text { s.t. } \quad & \sum_{\mathrm{k}}\left(\mathrm{S}_{\mathrm{k}, \mathrm{t}}-\mathrm{K}_{\mathrm{k}, \mathrm{t}}\right) \mathrm{a}_{\mathrm{k}, \mathrm{i}} \leq \overline{\mathrm{D}}_{\mathrm{i}, \mathrm{t}} \\
& \sum_{\mathrm{k}} \mathrm{C}_{\mathrm{k}, \mathrm{t}}\left(\mathrm{R}_{\mathrm{k}, \mathrm{t}}\right) \leq \overline{\mathrm{C}}_{\mathrm{t}} \\
\mathrm{R}_{\mathrm{k}, \mathrm{t}} \geq & \overline{\mathrm{Q}}_{\mathrm{k}, \mathrm{t}} \\
\mathrm{R}_{\mathrm{k}, \mathrm{t}} \leq & \mathrm{S}_{\mathrm{k}, \mathrm{t}}
\end{aligned}
$$

with $\mathrm{D}=$ maximum deposition in grid $\mathrm{i}$

C = available funds

Q $\quad$ reductions already agreed upon

In a second formulation deposition is minimized subject to budget constraints. Several budget constraints can be considered. In the case where countries already have agreed upon reductions the total amount of money 


\section{JEAN-PAUL HETTELINGH AND LEEN HORDIJK}

involved in these reductions could be considered as the minimum available budget. In addition to this limit to total European spending there might be a budget per country as well. Governments may state that they cannot spend more than a certain amount above the costs of the already agreed upon reductions. Alternatively a percentage of the gross domestic product might be used as a threshold.

$$
\begin{aligned}
& \min \sum_{k} \sum_{i} w_{i}\left(S_{k, t}-R_{k, t}\right) a_{k, i} \\
& \text { s.t. } \mathrm{R}_{k, t} \leq \mathrm{S}_{k, \mathrm{t}} \\
& \gamma_{k}^{\mathrm{V}} \mathrm{C}_{k, t}\left(\mathrm{Q}_{\mathrm{k}, \mathrm{t}}\right) \leq \mathrm{C}_{\mathrm{k}, \mathrm{t}}\left(\mathrm{K}_{\mathrm{k}, \mathrm{t}}\right) \leq \gamma_{\mathrm{k}}^{\mathrm{u}}\left(\mathrm{C}_{\mathrm{k}, \mathrm{t}}\left(\mathrm{Q}_{\mathrm{k}, \mathrm{t}}\right)\right.
\end{aligned}
$$

Target function (15) can be simplified by omitting the constants:

$$
\max \sum_{k} \sum_{i} w_{i} R_{k, t} a_{k, t}
$$

The weights $\mathrm{w}_{\mathrm{i}}$ can be formulated as a non linear increasing function of the deposition in target areas $i$. This would invoke larger reductions in areas with originally high depositions. The lower bounds on country budgets are added to avoid that countries with relatively low contributions to depositions in target areas would be assigned zero (or very low) reductions. Although such a low reduction would be optimal in an economic and atmospheric transport sense, it might be undesirable from a political point of view.

In the MODM formulations (14) and (15) deposition levels have been chosen as constraints respectively targets. Alternatively, soil and lake $\mathrm{H}^{+}$ concentration levels could be used.

In the foregoing objective functions were formulated taking into account uni-, bi- and multilater al policy frameworks. An implicit assumption behind the suggested policy objectives was for these to be evaluated for every time step t. An optimization of the time span within which a policy should be realized $w$ as left out of the discussion, since such an addition would not have added to a better understanding of possible policy conflicts as described in this paper. Finally, it should be noted that solutions to some multiple objective policies may be infeasible due to conflicting constraints in bi- and multilateral policy frameworks.

\section{Conclusions}

International deliberations on reduction of emissions in Europe until 1985 focussed on $\mathrm{SO}_{2}$. As of 1985 the second acidifying compound nitrogen oxides 


\section{ENVIRONMENTAL CONFLICTS: THE CASE OF ACID RAIN IN EUROPE}

(NO ${ }$ ) has been discussed. The model RAINS will be extended by taking into account emissions transport, deposition and effects of $\mathrm{NO}_{x}$. This will make RAINS more complex, since it is known that a long-range transport model for $\mathrm{NO}_{x}$ cannot easily be translated into a linear source-receptor matrix. It is assumed that negotiations on $\mathrm{NO}_{\mathrm{x}}$ reductions might take longer than the rapidly agreed $30 \%$ reductions for $\mathrm{SO}_{\%}^{\mathrm{X}}$. In collaboration with the $\mathrm{UN}$ Economic Comission for Europe RAINS will be further developed to a tool which could assist in these negctiations.

The MOLM problems formulated in this paper can be extended to include $\mathrm{NO}_{\mathrm{x}}$ targets. Also other constraints, like emissions per capita, per $\mathrm{km}^{2}$ or per PJ energy input will be considered. The introduction of the MODN concept in RAINS can make it a tool that changes its current setup into one that is part of the MCDM methods for Progressive Articulation of Preference Information Given [8, p. 102].

\section{A C KN OWLEDGMENTS}

The authors are grateful to Stuart Batterman who reviewed the manuscript and provided many valuable suggestions. Vicky Hsiung typed the various arafts of this paper skillfully. W'ork on the RAINS model is carried out in a multidisciplinary research team consisting of the authors and Joseph Alcamo, Markus Amann, Stuart Batterman, Jerzy Bartnicki, Gabor Kornali, Annikki Mäkela, Sergej Pitovranov, Wolfgang Schöpp and Miyoko Yamada. In earlier phases of the project the team benefited from the work of Maria Flolmberg, Juha Kämäri, Lea Kauppi, Pekka Kauppi, Maximilian Posch and Eliodoro Runca. Any errors in this paper are the authors' sole responsibility.

\section{RFFEREN CES}

1. Alcamo, J., L. Hlordijk, J. Kämäri, P. Kauppi, M. Posch and E. Funca, "Integrated Analysis of A cidification in Europe," Journal of Environm ental Managem ent, Vol. 21, 1985, pp. 47-61.

2. Alcamo, J., P. Kauppi, N:. Posch and E. Runca, "Acid Rain in Europe: A Framework to Assist Decision Making." Working Paper WP-84-32, International Institute for Applied Systems Analysis, Laxenburg, Austria, April 1984.

3. van Breemen, N., C. T. Driscoll and J. Mulder, "Acidic Leposition and Internal Proton Sources in Acidification of Soils and Waters," Nature, 307, 1984, pp. 599-604.

4. Brouwer, Floor, Jean-Paul Hettelingh and Leen Hordijk, "An Integrated Regional Nodel for Economic-Ecological-Demographic-Facility Interactions," Papers of the Regional Science Association, Vol. 52, 1983, pp. 87103.

5. Christophersen, N., and F. F. Wright, "Sulfate Budget and a Model for Sulfate Concentrations in Streamwater at Birkenes--A Small Forested Catchment in Southernmost Norway," Water Resour. Res., 17, 1981, pp. 377-389.

6. Economic Commission for Europe, "An Energy Efficient Future," London, 1983.

7. Eliassen, J., and J. Saltbones, "Modeling of Long Range Transport of Sulfur over Europe: A Two Year Model Run and Some Model Experiments," A tmospheric Environment, Vol.17, 1983, pp. 1457-1473. 
3. Hwang, Ching-hai and Alu Syed Md. Masud, "Multiple Objective Decision Making Niethods and Applications," Springer Verlag, Berlin-Heidelberg, 1979 , p. 13.

9. International Energy Agency, "Energy Statistics and Nain Historical Series 1983/1984," OECD, Paris, 1986.

10. Kamari, Juha, Maximilian Posch and Lea Kauppi, "A Model for Analyzing Lake Water Acidification on a Large Regional Scale, Part 1: Model Structure," Collaborative Paper CP-85-48, International Institute for Applied Systems Analysis, Laxenburg, Austria, December 1985.

11. Kauppi, P., Juha Kämäri, Maximilian Posch, Lea Kauppi and Egbert Niatzner, "Acidification of Forest Soils: A Model for Analyzing Impacts of Acidic Deposition in Europe, Version II," Collaborative Paper CP-85-27, International Institute for Applied Systems Analysis, Laxenburg, Austria, 1985 .

12. CECD. The CECD Program on Long-Range Transport of Air Pollutants. Measurements and Findings. 2nd Edition. Paris: Crganization for Economic Cooperation and Development, 1979.

13. Reuss, J. O., "Implications of the Calcium-Aluminum Exchange Systems for the Effect of Acid Precipitation on Soils," Journal of Environmental Quality, 12, 1983, pp. 591-595.

14. Fietveld, P., "Multiple Objective Decision Making and Regional Planning," Nor th Holland Publishing Company, Amsterdam, 1980, pp. 17-81.

15. Ulrich, B., "Theoretische Betrachtungen des lonen Irreislauf in Waldökosystem en," Pflanzenernährung Bodenkunde 144, 1981, pp. 647-659.

16. Ulrich, B., "Soil Acidity and its Relation to Acid Deposition," in: Ulrich, B., and J. Pankrath (ed.), "Effects of accumulation of air pollutants in forest ecosystems," Workshop Proceedings, Göttingen, FRG, May 16-19, 1982 , pp. 127-146.

17. Wetstone, G. S., and A. Rozencranz, Acid Rain in Europe and North America. Washington D.C.: Environmental Law Institute, 1983. 
